\title{
Management Information System and Effective Service Delivery in Kwara State Polytechnic, Ilorin
}

\author{
Akewusola Lanre \\ Office Technology Management Department \\ Kwara State Polytechnic, llorin, Nigeria
}

\begin{abstract}
The role of information in decision-making cannot be over stressed. Effective decision-making demands accurate, timely, and relevant information. The use of information systems has increased in the last decade not only by the firms but also by the individuals, and even educational institutions. The deployment of Information System was encouraged by the technological breakthroughs; the advancements in telecommunications such as the internet, the globalization that created a world-wide unlimited marketplace, the strong growing for information economy, the rise of competitive digital firms and institutions. The importance of Management Information System (MIS) in tertiary institutions has evolved over time and become an integral part of educational operations in Nigeria. This paper presents MIS and effective service deliveries and prospects of MIS in Kwara State Polytechnic, Ilorin. The tool employed for this study was structured questionnaire and data collected were analysed using frequency table, simple percentage and bar chart. 100 respondents were randomly selected for the study. The study revealed the low utilization of MIS within the polytechnic by the three groups of respondents for effective service-delivery. It was also found that MIS was not adequate in the Polytechnic for teaching, learning and administrative work. The study recommends, among others, effective linkage of all the information systems to enhance its usage to the benefit of all its stakeholders.
\end{abstract}

\section{Keywords}

Management Information System, Effective Service Delivery, Teaching and Learning

\section{INTRODUCTION}

The rapid development of information technology coupled with the development of telecommunications technology has streamlined every area of life and human activity. Through good organization of this technology; it has become possible to achieve quality decision-making at all levels of management from the top-level to the lowest (Berisha-Shaqiri, 2014). According to Bright and Asare (2019), the information needs of modern organizations, especially university institutions have become quite enormous and challenging to the extent that every institution needs to pay great attention to how information is gathered, stored, disseminated and utilized (Ijeoma, 2018). Information technology in organizing the best and optimal database offers great opportunities for a quick and qualitative manipulation to raise the quality of the preparation of decisions. Management Information System (MIS) is flow-processing procedure based on computer data, and integrated with other procedures to provide timely and effective information for management functions and decisionmaking (Berisha-Shaqiri, 2014). MIS is an information system that generates accurate, timely, and organized information so that managers and other users can make decisions, solve problems, supervise activities, and track progress (Yusuf, Isyaka \& Aina, 2014). Because it generates reports on a regular basis, a management information system sometimes is called a Management Reporting System (MRS). A MIS focuses on generating information that management and other users need to perform their jobs. A tertiary institution is strictly involved in teaching, learning, researching, and community service. These activities require large doses of information generation and knowledge distribution. At the core of the activities is information. However, information resource is one of the major issues and indices of planning in a tertiary institution; where the relevant information required for planning are not available at the appropriate time, there is bound to be poor planning, inappropriate decision-making, poor priority of needs, defective programming or scheduling of activities (Yusuf, Isyaka \& Aina, 2014). Hence, tertiary institutions' system will not be efficient and effective in its operation (Ijeoma, 2018). Poor management information system has been identified as a bottleneck in the successful management of tertiary institutions in Nigeria. Also, Obi (2003), Fabunmi (2003) and Adebayo (2007) have stressed the need for MIS in making effective decisions in educational institutions. Similarly, Ajayi and Omirin (2007) believe that the importance of MIS in decision-making can be realized from its aim and objectives. MIS aims at developing a viable system that maximize the effective use of modern data approach to management practices and assisting managers to obtain accurate and timely information.

\section{STATEMENT OF THE PROBLEM}

Information is a generic term because it has been described as the live wire of any enterprise or institution (public, private, local firm, Multinational Company, manufacturing, merchandise, and franchise business, retailing stores, multiple chains stores or service-oriented organization). It provides the relevant concept and intelligence to enable the right thing to be done at the right time. Observation has enabled the researcher to pose the questions: Is there any need for MIS in Kwara State Polytechnic Ilorin or any tertiary institution? Does the status of a tertiary institution determine the type of information system in it? Does MIS aid service delivery in Kwara State Polytechnic, Ilorin? Could there be any room for development or improvement of MIS in Kwara State Polytechnic, Ilorin?

\section{OBJECTIVES OF THE STUDY}

The objectives of the study are to:

i. Investigate the availability and the extent of the development of MIS in Kwara State Polytechnic, Ilorin;

ii. Evaluate whether MIS application provides users with timely, accurate, consistent, complete, and relevant information of Kwara State Polytechnic, Ilorin; 
iii. Determine whether MIS application and enhancement system exist to adequately support teaching and learning in Kwara State Polytechnic, Ilorin; and

iv. Identify how MIS has enhanced effective servicedelivery in Kwara State Polytechnic, Ilorin.

\section{LITERATURE REVIEW}

A number of researches have been carried out to explore diverse areas in MIS. MIS is a subset of the overall internal control of a business covering the application of people, documents, technologies, and procedures by management accountants to solve business problems such as costing a product, service or a business-wide strategy. MISs are distinct from regular information systems in that they are used to analyse other information systems applied in operational activities in the organization. Yusuf, Isyaka and Aina (2014) proposed a study that highlights the impact of management information system in Nigerian Business Organizations. It intends to determine how the information system helps an organization to perform effectively. The study recommends that business organization should introduce flexibility in the nature or pattern and structure of MIS; attention should also be paid to communicate through the media agencies as a way of promoting the company's control of the market as well as acquiring appropriate and suitable computer software and program to meet MIS ever- growing status and expansion in the global business market environment

In addition, Ajayi and Omirin (2014) conducted research on the use of Management Information Systems (MIS) in decision-making on long-term planning, short-term planning and budgeting in the South-West Nigerian Universities. The study used the descriptive research design of the survey type. Based on their findings, MIS was not adequately used for decision-making on long-term planning, short-term planning and budgeting in the universities. Moreover, while ownership (Federal or State) did not make a difference in the use of MIS for decision-making process on long-term and short-term planning, it made a difference in decision-making process on budgeting. It is, therefore, recommended that the MIS units should be adequately financed and maintained to ensure free flow of information and adequate use of MIS in decision-making on long-term and short-term planning as well as budgeting. Moreover, Bright and Asare (2019) conducted a study aimed to identify the impact of Management Information System (MIS, hereafter) in the University of Education Winneba, Kumasi Campus. Specifically, it assessed the adequacy of available MIS and their utilization by the students, lecturers and senior administrative staff of the University of Education Winneba, Kumasi campus in support of administrative works, teaching and learning. The findings of their study clearly show that MIS has improved teaching and learning, and it has enhanced or modified the learning process. It was also clear that UEW-K is inadequately equipped for MIS operations (especially electronic equipment). The available MIS equipment was not sufficient to be utilized by students, lecturers and senior administrative staff within the university campus. To enhance administrative decision processes, so that decision-making, policy analysis, formulating, planning, monitoring and management at all levels can be a reality, effective MIS operation should be adequately available.

\section{MANAGEMENT INFORMATION SYSTEM}

Concepts Information management has been defined as the organization-wide capability of creating, maintaining, retrieving and making immediately available the right information in the right place, at the right time, in the hands of the right people at the lowest cost, in the best media, for use in decision-making (Ajayi \& Omirin, 2014).

Management information system is a system, which is designed to provide information to various organizational levels to assist them in decision-making. The growing complexity of business organizations also increases the quantum of points at which decision must be made, ranging from individual decision-maker at the lowest operating levels to strategic decision-maker at the top. Management information system is a system of people, equipment, procedures, documents, and communication, that collects, validates, operates, transforms, stores, retrieves, and presents data for use in planning, budgeting, accounting, controlling, and other management processes. MIS is structured to provide the information needed when needed, and where needed. Furthermore, the system represents the internal communication network of the business providing the necessary intelligence to plan, execute and control. MIS can also be defined as a support to management to provide the competitive advantage which must support the goals of the organization.

Yaser, Alina and Nor (2014) defined MIS as a planned system of collecting, processing, storing, disseminating data in the form of information needed to carry out the functions of management. It can also be documented reports of the activities, planned and executed. An effective management information system typically employs computer and other sophisticated technology to process information that reflects the day-to-day operations of the company. Based on the above, management information system is an integrated manual computer system that provides information to support the operations of managements, and the decisionmaking functions of a company.

Management information system is also a collection of people, procedures, and devices organized to convert to data from internal and external sources into information and communicate such information in an appropriate form to management at all levels. The objectives of management information systems are the provision of information to all levels of management at the most appropriate time at an acceptable level of accuracy and at an economical cost, such information is used in the decision-making process for modifying the state of system by taking appropriate action (Markgraf, 2017). An essential requirement of MIS is feedback, which is the process of communicating a system measured output to control system which generates effective control system, normally a manager in respect of a business system. It is these factors which allow the state of a system to be modified.

\section{METHODOLOGY}

\section{Population and Sample}

The target population for this study is the staff and students of Kwara State Polytechnic, Ilorin; chosen as a case study; 110 questionnaires were distributed; the response rate was $90.9 \%$ (100 usable responses).

\section{Data Collection}

i. Secondary data was collected based on the finding of published papers, articles, books, previous, studies, and the World Wide Web. 
Primary data collection was carried out using a selfdesigned questionnaire. The adopted instrument comprises two sections, the first sections covers demographic information (Name, Department, Institute, Age, and Gender) while the second section contains nine(9) items measuring the awareness of MIS and effective service delivery in Kwara State Polytechnic, Ilorin to use the MIS systems.

\section{Data Analysis Methods}

Descriptive techniques such as Frequencies, Percentages and bar chart were used to describe variables.
7. RESULT AND ANALYSIS

Information Systems used in Kwara State Polytechnic, Ilorin

The following Information Systems- Transactional Processing Systems (TPS), Management Information System (MIS), Decision Support System (DSS), and Executive Information System (EIS) were assessed to know how often they are used by students, lecturers and the administrative staff for administrative process, teaching and learning in Kwara State Polytechnic.

Table 1: Type of IS used in Kwara State Polytechnic, Ilorin

\begin{tabular}{|l|c|c|}
\hline \multicolumn{1}{|c|}{ Type } & No of Respondents & Percentage (\%) \\
\hline $\begin{array}{l}\text { Transactional Processing } \\
\text { Systems (TPS) }\end{array}$ & 8 & 8 \\
\hline $\begin{array}{l}\text { Management Information } \\
\text { System (MIS) }\end{array}$ & 82 & 82 \\
\hline $\begin{array}{l}\text { Decision Support System } \\
\text { (DSS) }\end{array}$ & 6 & 6 \\
\hline $\begin{array}{l}\text { Executive Information } \\
\text { System (EIS) }\end{array}$ & 4 & 4 \\
\hline Total & $\mathbf{1 0 0}$ & $\mathbf{1 0 0}$ \\
\hline
\end{tabular}

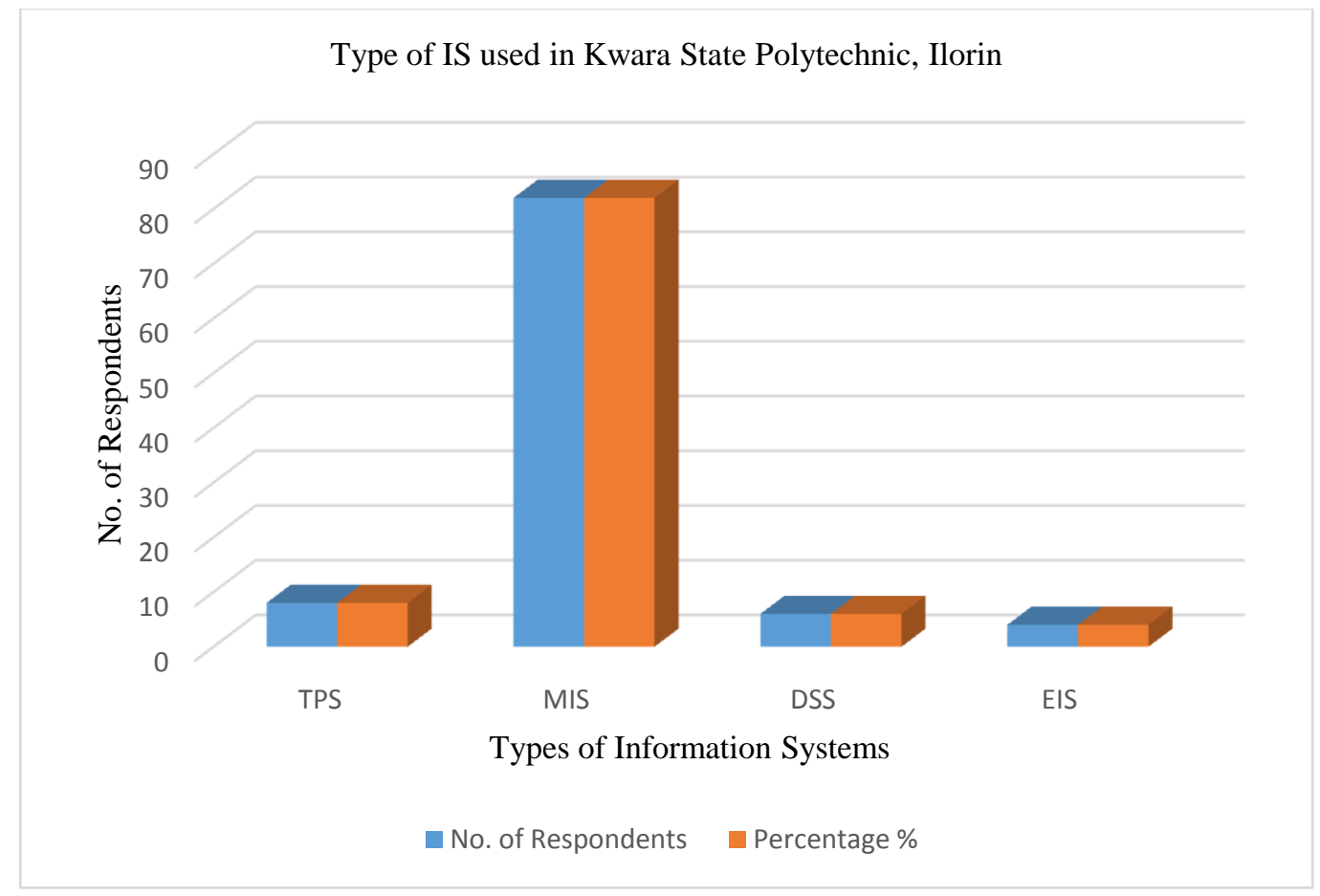

Figure 1: Bar chart showing the type of IS used in Kwara State Polytechnic, Ilorin

Table 1 and figure 1 indicate the various types of Information Systems in Kwara State Polytechnic, Ilorin, which shows that 8 respondents which represent $8 \%$ TPS, MIS representing
$82 \%$, while $6 \%$ and $4 \%$ represent DSS and EIS respectively. This shows that MIS are used by the lecturers, administrators and the students to achieve a set target.

Table 2: MIS has helped in achieving teaching, learning or administrative work

\begin{tabular}{|l|c|c|}
\hline Items & No of Respondents & Percentage \\
\hline Yes & 77 & 77 \\
\hline No & 23 & 23 \\
\hline Total & $\mathbf{1 0 0}$ & $\mathbf{1 0 0}$ \\
\hline
\end{tabular}


MIS has help in achieving my teaching, learning or administrative work

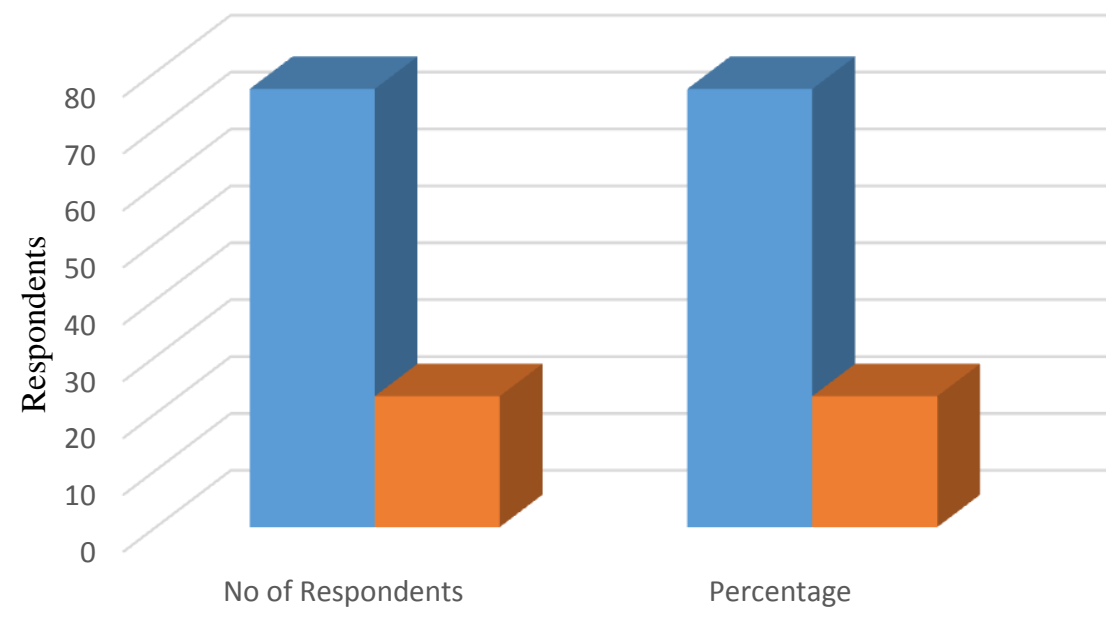

Axis Title

$\square \mathrm{YES} \square \mathrm{NO}$

Figure 2: Bar chart showing how MIS has helped in achieving teaching, learning or administrative work

From table 2 and figure 2, it is clearly indicated that MIS has helped $77 \%$ of the respondents in achieving their work, while 23 of the respondents representing $23 \%$ have not been able to reach their target. This concludes that MIS is being utilized well within the school because the majority of the respondents have realised their intended goals.

Table 3: Easy Accessibility of Information Systems in the Polytechnic

\begin{tabular}{|l|c|c|}
\hline Item & No of Respondents & Percentage \\
\hline Computer /Cyber-Café & 23 & 23 \\
\hline Android Phone & 21 & 21 \\
\hline Wireless Internet Connection & 3 & 3 \\
\hline e-Library & 6 & 6 \\
\hline Notice Board & 47 & 47 \\
\hline Total & $\mathbf{1 0 0}$ & $\mathbf{1 0 0}$ \\
\hline
\end{tabular}




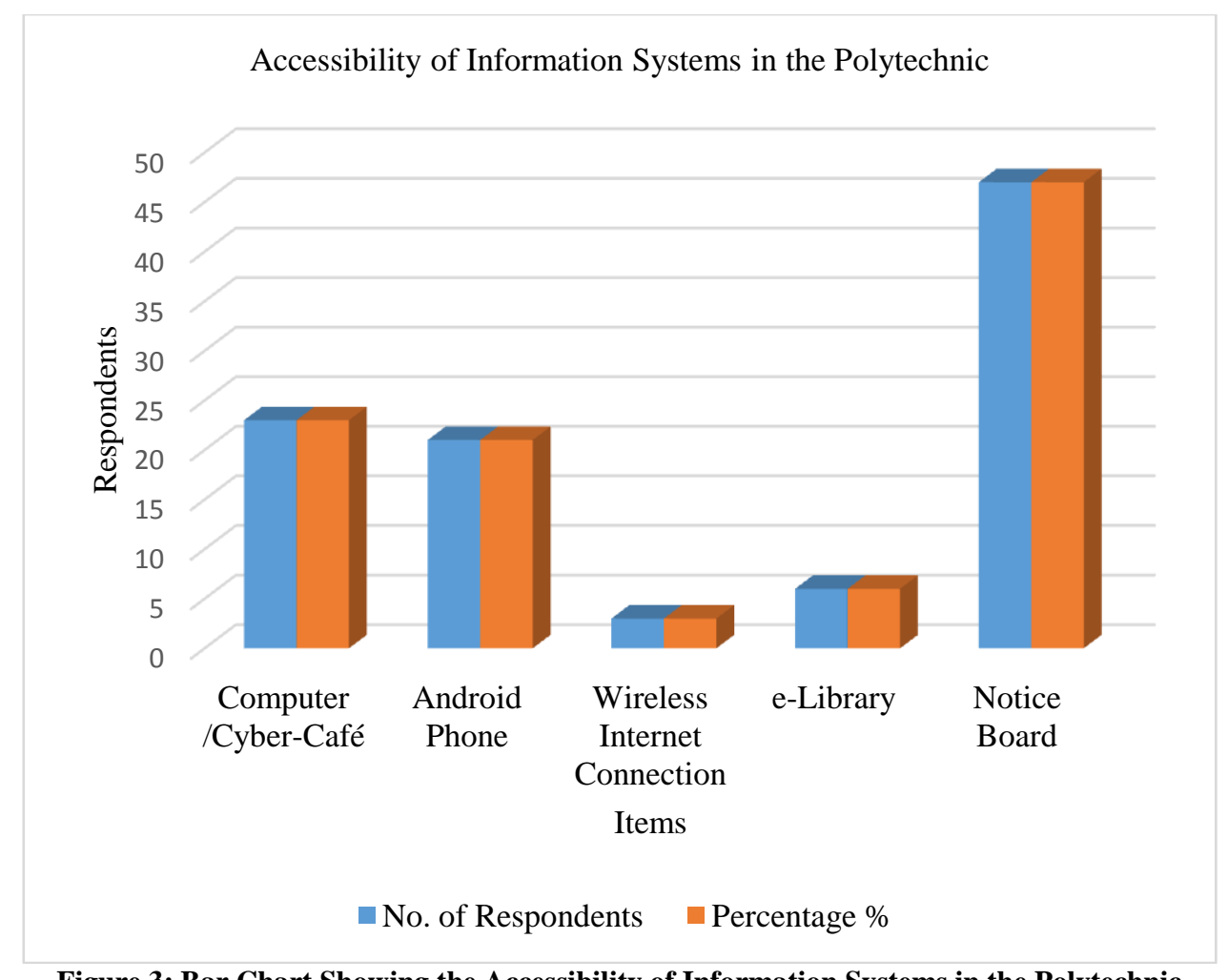

Figure 3: Bar Chart Showing the Accessibility of Information Systems in the Polytechnic

Table 3 and figure 3 depict how the respondents got access to the information systems available on the campus. From the table, easy access to notice board formed $47 \%$, e-library consists of $6 \%$, wireless internet connection was $3 \%$ according to the respondents, and computer/ Cyber-Cafe recorded $23 \%$ while $21 \%$ of the respondents used their Android phones.

Table 4: MIS has made Online Registration Easy

\begin{tabular}{|l|c|c|}
\hline Items & No of Respondents & Percentage (\%) \\
\hline Yes & 82 & 82 \\
\hline No & 18 & 18 \\
\hline Total & $\mathbf{1 0 0}$ & $\mathbf{1 0 0}$ \\
\hline
\end{tabular}

Online Registration is made easy with MIS

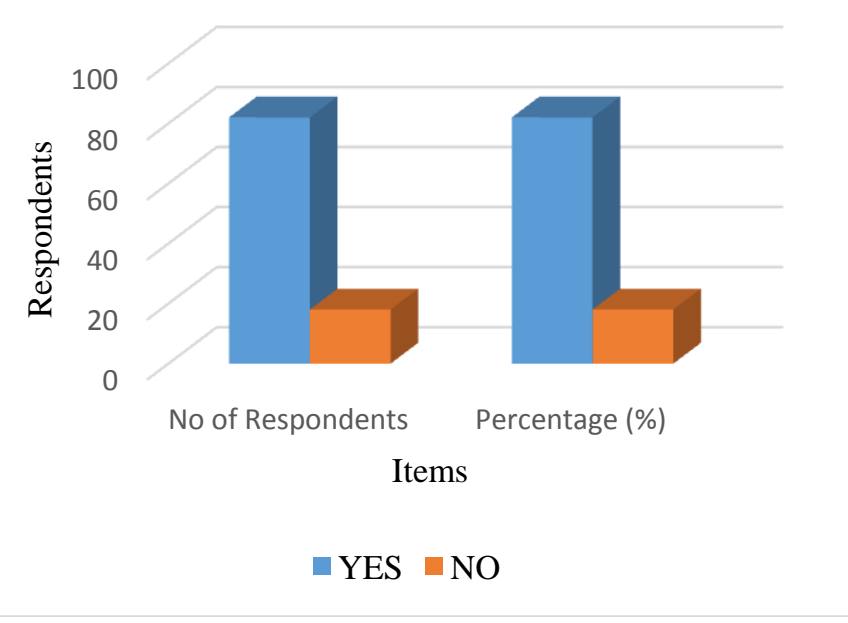

Figure 4: Bar Chart showing whether MIS has made Online Registration easy or not 
Table 4 and figure 4 depict how MIS has improved registration process through the use of internet facilities within the campus. 82 of the respondents representing $82 \%$ acknowledged that internet services have really facilitated the registration process and $18 \%$ of them expressed negative opinion.

Table 5: MIS has made class presentations effective

\begin{tabular}{|l|c|c|}
\hline Items & No of Respondents & Percentage (\%) \\
\hline Yes & $\mathbf{7 4}$ & $\mathbf{7 4}$ \\
\hline No & $\mathbf{2 6}$ & $\mathbf{2 6}$ \\
\hline Total & 100 & 100 \\
\hline
\end{tabular}

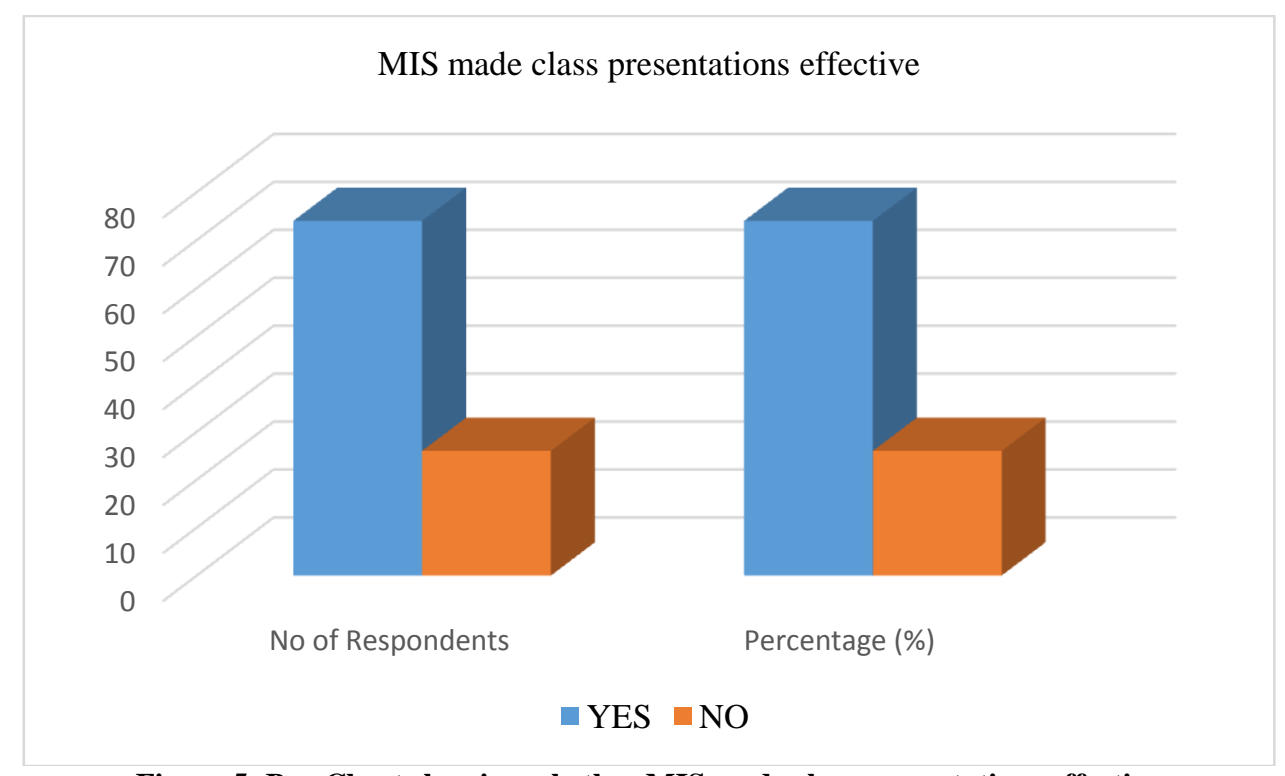

Figure 5: Bar Chart showing whether MIS made class presentations effective

Table 5 and figure 5 indicate that 74 of the respondents representing 74\% stated that MIS has made class presentation effective, while $26 \%$ of the respondents answered negatively to show how ineffective it has been to them.

\section{DISCUSSION OF RESULTS}

From the table, the researcher has TPS, MIS, DSS and EIS respectively, MIS represents $82 \%$, While TPS represents $8 \%$, DSS represents $6 \%$, EIS represents $4 \%$ which shows that the other three are used on few occasions. These systems are used by the lecturers, administrators and the students to achieve a set target. There is interrelationship among these MIS systems and effective service delivery in the institution. It was found in table 3 that access to notice board formed $47 \%$, e-library consists of $6 \%$, wireless internet connection was $3 \%$ according to the respondents, and computer/cyber-cafe recorded $23 \%$ while $21 \%$ of the respondents' ticked access to their Android phones. The result shows that computer which forms the basis for management information system is not adequately available and easy to access on the campus. Also, table 4 shows that $82 \%$ of the respondents agreed that the use of MIS in the polytechnic has enhanced easy registration compared to the old traditional method of registration, while $18 \%$ are of the negative opinion. In addition, table 5 and figure 5 indicate that $74 \%$ of the respondents stated that MIS has made class presentation effective, while $26 \%$ of the respondents answered negatively to show how ineffective it has been to them. Hardware and software components of MIS have impacted on the quality of services and usage of MIS in the polytechnic. Thus, this finding of inadequate MIS equipment in the Polytechnic does not conform to the standard requirements of effective MIS operations in complex organizations, such as the polytechnics. Absence of such MIS equipment would interfere with administrative duties, lecturers' research performance and the students' ability to contribute to knowledge in all endeavours.

\section{CONCLUSION}

The results of findings of this study clearly indicate that MIS has improved teaching and learning and it has also enhanced or modified the learning process. Similarly, based on the findings of this study, MIS is useful in the area of decision making as it can monitor by itself disturbances in a system, determine a course of action and take action to get the system in control. However, it was also clear that Kwara State Polytechnic, Ilorin is not adequately equipped for MIS operations, especially electronic equipment and internet connectivity. The available MIS equipment was not adequate to be utilized by students, lecturers and administrative staff within the Polytechnic main campus. To enhance administrative decision processes, effective MIS is required for timely decision-making, policy analysis, formulating, planning, monitoring and management at all levels to be a reality.

\section{RECOMMENDATIONS}

From the research conducted, the following recommendations were made:

i. For effective MIS operations in Kwara State Polytechnic, computers and their accessories are necessary. Other related technologies of MIS such as telephone system, internet, fax, notice board, suggestion box and e-mail services need to be provided to ensure appropriate and adequate dissemination of necessary information within and outside the Polytechnic system. 
ii. The government should assist the Polytechnic in providing these MIS equipment in order to perfect the network design, which is the goal to enhance MIS project between the Polytechnic campuses.

iii. Additionally, people within the Polytechnic should be made aware of the available MIS equipment. They should be distributed to serve the different categories of Polytechnic personnel in line with their prescribed roles towards goal attainment.

iv. Lecturers in particular should be provided with necessary equipment and properly trained to use them for their professional development and academic improvement of their students. These measures would go a long way to improve the standard of polytechnic education. Students would benefit from lecturers research work and ultimately improve their knowledge in their domains of studies.

v. Finally, effective maintenance system should be adopted to strengthen the operation of MIS in Kwara State Polytechnic. Routine programmes and contingency measures should be put in place to ensure perpetual existence of the various MIS technologies and its supporting devices. This will solve the problem of inadequacy of equipment on the campus. It will also ease the challenges students encounter in the course of one activity or the other.

\section{REFERENCES}

[1] Berisha-Shaqiri, A. (2014). Management Information System and Decision-Making. Academic Journal of Interdisciplinary Studies, 3(2): 19-23.

[2] Bright, A. A. \& Asare, G. (2019). The impact of management information system on university of education Winneba, Kumasi Campus-Ghana. European Journal of Research and Reflection in Management Sciences, 7(1): $1-20$.

[3] Ijeoma, M. M. (2018). Importance of management information system in service delivery and paper work in Nigeria university. IOSR Journal of Business and Management, 20(9): $30-38$.

[4] Berisha-Shaqiri, A. (2014). Management Information System and Decision-Making. Academic Journal of Interdisciplinary Studies, 3(2): 19-23.

[5] Yusuf, M., Isyaka, M. S. \& Aina, O. A. (2014). The Impact of Management Information System (MIS) on the Performance of Business Organization in Nigeria. International Journal of Humanities Social Sciences and Education (IJHSSE, 1(2): 76 - 86.

[6] Ijeoma, M. M. (2018). Importance of management information system in service delivery and paper work in
Nigeria university. IOSR Journal of Business and Management, 20(9): 30 - 38.

[7] Yusuf, M., Isyaka, M. S. \& Aina, O. A. (2014). The Impact of Management Information System (MIS) on the Performance of Business Organization in Nigeria. International Journal of Humanities Social Sciences and Education (IJHSSE, 1(2): 76 - 86.

[8] Obi, E. (2003). Educational Management: Theory and Practice. Enugu: JAMOE Nigeria Enterprises.

[9] Fabunmi, M. (2003). Management Information Systems in Education, in Babalola JB (ed.). Basic Text in Educational Planning. Ibadan: Department of Educational Management, University of Ibadan, Ibadan.

[10] Adebayo, F. A. (2007). Management information system for managers. Ado-Ekiti: Green Line Publishers.

[11] Ajayi, I. A. \& Omirin, F. F. (2007). The use of Management Information Systems (MIS) in decisionmaking in South-West Nigerian Universities. Educational Research and Review, 2(5): 109-116.

[12] Yusuf, M., Isyaka, M. S. \& Aina, O. A. (2014). The Impact of Management Information System (MIS) on the Performance of Business Organization in Nigeria. International Journal of Humanities Social Sciences and Education (IJHSSE, 1(2): 76 - 86.

[13] Ajayi, I. A. \& Omirin, F. F. (2007). The use of Management Information Systems (MIS) in decisionmaking in South-West Nigerian Universities. Educational Research and Review, 2(5): 109-116.

[14] Bright, A. A. \& Asare, G. (2019). The impact of management information system on university of education Winneba, Kumasi Campus-Ghana. European Journal of Research and Reflection in Management Sciences, 7(1): $1-20$.

[15] Ajayi, I. A. \& Omirin, F. F. (2007). The use of Management Information Systems (MIS) in decisionmaking in South-West Nigerian Universities. Educational Research and Review, 2(5): 109-116.

[16] Yaser, H. A., Alina, S., \& Nor, A. (2014). The Meaning of Management Information Systems and its Role in Telecommunication Companies in Yemen, Malaysia; American Journal of Software Engineering, 2(2): 22-25.

[17] Markgraf, B. (2017). Importance of Information Systems in an Organization. Available at http://smallbusiness.chron.com/importance-informationsystems-organization-69529.html, retrieved on 12/11/2019. 